\title{
VELHICE E CASAMENTO
}

\section{(Aspectos psiquiátrico-legais)}

\author{
Napoleão L. TEIXEIRA \\ Professor de Medicina Legal da Faculdade de \\ Direito da Universidade do Paraná
}

\section{PRELIMINARES}

Não é fácil definir, com exatidão, o que seja a velhice. Assinala-o Raitzin, escrevendo ser um estado sumamente complexo de definir, por la diversidad caótica con que la matizan algunos de sus caracteres fisiológicos. Para Littré, velhice seria période de la vie humaine, dont on fixe le commencement à la soixantième année, mais qui peut être retardée ou avancée suivant la constitution individuelle, le genre de vie et une foule de circonstances. 0 que é exato, por isso que, ao lado de anciães na idade fisiológica, rigorosamente jovens no físico e no espírito (agerasia, verte vieillesse dos francêses), há, por igual (e são cada vez mais numerosos), os jovens na idade, mas velhos, velhíssimos no físico e no espírito (progéria ou senium praecox).

São, pois, relativos os limites que se pretende dar à velhice. Relativos e falhos. Falhos e arbitrários. O limite de idade é, ao ver de Minkowski, "aspecto administrativo e arbitrário da vida", ou, como queria Afrânio Peixoto, limite dado, arbitràriamente, pelas leis. Porque há velhice e velhice: velhice 
aparente e velhice não aparente; velhice inoperante, verdadeira, e velhice sadia, robusta, feliz - agerasia chamada. Razão de haver Nina Rodrigues ponderado que, à cláissca fórmula de Cazallis - o homem tem a idade das suas artérias (Der Mensch ist so alt sie seine Gefasse) - se pode, melhor, dar, nêste particular, o enunciado equivalente: "o vigor mental tem a idade da resistência cerebral". Mesmo porque - conceito de Levi il y a des cerveaux de veiellards qui ne sont pas des cerveaux sénilles.

A maioria das nações civilizadas fixa o limite em referência aos 60,65 e mesmo 68 e 70 anos. Entre nós, estatui a Constituição seja o funcionário público civil aposentado, compulsóriamente, aos 70 anos (art. 191, n. ${ }^{\circ}$ II); no que diz respeito às Fôrças Armadas, a idade limite para permanência no serviço ativo, nos pôstos de general-de-exercito, almirante-de esquadra e tenente brigadeiro (os mais altos a que, na ativa, se pode, normalmente, chegar), é de 66 anos. Nosso Código Penal, considerando, como atenuante, ser o agente.. ..... maior de 70 anos (art. 48, I) admite, implìcitamente, que a involução senil tem comêço naquela idade. "Naturalmente, é um limite legal que nem sempre a realidade confirma" - ensina Flamínio Favéro. O Código de Processo Penal, em seu artigo 434, isenta os maiores de 60 anos do alistamento para o serviço do júri. A Consolidação das Leis do Trabalho estabeleceu que sòmente será permitido o trabalho no sub-sólo aos compreendidos entre 21 e 50 anos (art. 301), devendo, a partir desta idade, serem transferidos para a superfície. A própria Igreja dispensa da lei de jejum os menores de 21 e os maiores de 60 anos (Raoul Naz - "Traité de Droit. Con", t III, Can. 1254, § $2^{\circ}$ )

As companhias de seguro admitem, em suas tabelas, diversos limites de vida provável. Ao passo que algumas presumem o término normal da vida aos 60 , fazem-no outras, aos 65 e aos 70 anos.

Nossa Constituição, nossa legislação civil e militar, com seus dispositivos, de que demos notícia, estatuindo o afastamento compulsório do individuo das suas atividades ao alcançar determinada idade, reconhecendo necessidade de um tratamento especial para os idosos - admitem, implicitamente, que a velhice, mesmo fora da senilidade, sem falar da demência senil, implica em diminuição da capacidade de trabalho do individuo. $\mathrm{O}$ que se, até certo ponto, é verdade, de modo algum é verdade absoluta. 
Embora reconhecendo que a velhice se faz sentir por uma diminuição energética, lembra Afrânio Peixoto que os trabalhos especializados, de destreza, delicadeza, de manóbra e o trabalho de direção espiritual, como que se afinam com a idade. Mas, isso é trabalho "especial" e não conta para o nosso caso que é do trabalho "mecânico" ou trabalho "funcionário" acentua.

Têm-se mesmo estudado, em alguns países, os problemas de readaptação e reaproveitamento do operário e do artífice envelhecidos, em mistéres consentâneos com suas fôrças e possibilidades. Na Suíça e outras nações européias, durante a guerra mundial II, octogenários e nonagenários foram aproveitados. "Llegará el dia en que se tenga de legislar también el trabajo en la vejez sobre una base enteramente cientifica" observa Gorriti.

Oferecem os estados de involução senil aspectos que dizem respeito ao fôro cível e criminal. Isso, sem contar com outros, referentes ao direito administrativo, trabalhista, etc.

Procuraremos, no presente artigo, abordar alguns aspectos (alguns, não todos - observe-se) dos estados em aprêço, relativamente a questões condizentes com a velhice e o casamento. Não como jurista - que não somos - mas como Professor de Medicina Legal, ex-Professor de Clínica Psiquiátrica e, principalmente, como psiquiatra militante na clínica há perto de cinco lustros.

Procuraremos... Se nada de bom nos fôr dado fazer, salve-se, ao menos, a intenção. Mesmo porque, já o dizia Pasteur, nul éffort est perdu.

Isso assentado, entremos no assunto CAPACIDADE MATRIMONIAL, NA VELHICE

- Que é o casamento? Divergem as opiniões Para Monteiro Lobato, "é o nosso serviço militar obrigatório" Para Maupassant, é "mistura de máus humores durante o dia e de máus odores durante a noite. Para Alvaro Moreyra, "um impôsto que se paga à felicidade; aos ricos, o impôsto não perturba, mas os pobres se vềem tontos com êle: pagam sempre com 
multa". Houve alguém que acreditava ser, o casamento" uma sociedade onde a gente se aborrece: solidão a dois". Para um personágem de Victor Hugo, "le mariage est une greffe; cela prend bien ou mal". Para a irreverência de Bernard Shaw, "o amor é a estrêla para a qual o homem olha, com êxtase; o casamento é o buraco em que cai, enquanto olha para a estrêla". Na opiniãode Byron", o casamento nasce do amor como o vinagre do vinho; é uma beberágem de gôsto pouco agradável e ácido, à qual o tempo fêz perder o celeste aroma, para transformá-la em. simples tempêro de cozinha, insípido e comum". Acredita, melancòlicamente, Afrânio Peixoto que o casamento transforme 0 o amor - êsse simpático boêmio - num funcionário; com o ponto, as licenças e até aposentadoria. Laurindo Rebelo, boêmio carioca, costumava dizer que se o mar se casasse, por certo se amansaria... O neurótico Schopenhauer achava que casar-se "é o mesmo que pôr, às cegas, a mão num saco fechado, esperando agarrar uma enguia num emaranhado de cobras". Entendia Oscar Wilde que "a melhor base para o casamento é a mútua... incompreensão". Lemos algures que, nos Estados Unidos "o casamento é o... divórcio", ao que conhecido humorista, precisando melhor, explicou:" o casamento é a primeira etapa de vida nova, cujo limite natural é o divórcio". Talvez seja assim, em U. S. A.; conta-se que, há pouco, o americano Ernest Bates, apenas saído da igreja, em que acabava de se casar, abraçou sua jovem espôsa e partiu, correndo, para assistir uma partida de futebol; queixava-se, mais tarde: "Infelizmente, cheguei atrazado! u'a maçada!"

Até aqui, com a palavra os que falam mal do casamento. Há, porém, os que o defendem (nós, inclusive), e são muitos. Contrapondo-se a Kaiserling, que conceitua o matrimônio como "um conflito", acrescenta Holmes: "Sim, é um conflito porque, nêle, dois sêres diferentes tratam de viver a mesma vida, não sendo, porém causa de infelicidade, desde que, entre êles, haja compatibilidade sexual e moral". Um certo autor ianque entende que "a good marriage is a good investment". Mare Girandin opina: "O casamento tem o duplo mérito de dar ao amor a fôrça de uma lei e, à lei, a doçura de uma afeição". 
Deixando de parte opiniões pró e contra, lembremos que jamais se dirá bastante bem do matrimônio - modalidade de migração (*) espontânea e natural - nem serão jamais excessivos os louvores que se entoem ao casamento, "de tôdas as ações humanas a que mais interessa à Sociedade", ao dizer de Montesquieu.

E o particular caso dos velhos casos, há - e muitos - de sênios que, malgrado a idade avançada, não hesitam em se ca- sar, sendo que alguns o fazem duas e mais vezes. O holandês Chisten Drakenburg casou-se aos 111 anos e, após a morte da espôsa, propôs casamento a várias mulheres, e tinha então 130 anos. Thomas Parr, que viveu 152 anos, se casou diversas vezes, sendo que, a última, aos 105 anos. 0 filósofo Bertrand, Russel casou-se aos 80 anos com a jovem Edith Finch. Charles Chaplin casa-se aos 54 anos com Oona O'Neil, de 18 anos, que deu ao genial artista 6 filhos e anos de tranquilidade, depois da mais tormentosa das vidas. Núpcias da juventude com a música às da encantadora Martita Montez, de 20 anos, com o octogenário músico Pablo Casals. Casamento de maio com dezembro, o da bela, encantadora e milionária Glória Vanderbilt (18 anos) com o famoso regente Leopold Stokowski (58 anos). $\mathrm{E}$, quase todos, casamentos fecundos, concretizados em filhos - casamentos afirmados, pois. E não casamentos "brancos", como o do velho banqueiro Jacques Récamier, a 24 de abril de 1793 (5 Floréal, ano I), com aquela que viria a ser Mnce Recamiér uma das mais famosas mulheres do fim do século revolucionário e primeira metade do século XIX; que acentuando o extraordinário dêsses matrimônio, mostra um biógrafo que o marido "ne réclama jamais les droits qu'il avait sur son épouse, et que celle-ci sortit de ses bras vièrge comme ele s'y était jetée". 0 envelhecer - tragédia suprema na vida da mulher - traz, por vezes, compensações à criatura feminina; daí, o conselho de

(*) Migração, usada, aqui, em um sentido lato, como a interpreta Delmas, não sòmente como uma mudança de lugar, mas também como mudança de estado, de situação. Estuda o ilustre mestre gaulês a migração no sentido ordinário, "de um lugar para outro", no sentido de uma etapa social (de uma situação para outra), no domínio intelectual (gôsto artístico, paixão política, gostos religiosos, etc.) 
Ágatha Christie a u'a mocinha: "Case-se com um arqueólogo; quanto mais velha ficar, mais seu marido lhe encontrará encantos" - e bem deve saber por que o diz, de vez que seu espôso é arqueólogo...

Respeito ao matrimônio, estabelece nosso Código Civil obrigatoriedade de separação de bens no casamento do maior de 60 ou da maior de 50 anos. Qual o critério adotado pelo legislador, nêste particular? Pressuporia nos nubentes, naquelas idades, uma minusvalia psíquica que lhes tolhesse o discernimento, relativamente a êsse ato de tão elevado alcance social? Ou prevaleceria o critério da proteção econômica dos mesmos? É dêste parecer Afrânio Peixoto, ao especificar que a restrição, no caso em aprêço, "visa antes a defêsa da pessoa na indevida exploração de seus bens, uma vez que um, ou os cônjuges, já não devem ter... aptidão geradora que justifique a plena franquia do casamento". Seria, esta, a interpretação mais exata.

Entre as moções apresentadas ao II Congresso de Medicina Legal e Criminologia (Recife 1956), dizendo respeito a possível refórma futura do Código Civil, Hélio Gomes apresentou a seguinte:

"Não será permitido o casamento quando, entre os pretendentes, houver diferença de idade superior a 25 anos".

Em que pese a nossa grande admiração pelo ilustre Mestre da Medicina Legal pátria, achamos arriscado o novo dispositivo, caso venha a vingar. É que, assim como há moços-moços e moços-velhos, há velhos-velhos e velhos-moços. Por isso que - fato sabido - a idade cronológica nem sempre corresponde à idade fisiológica. Que representa uma diferença de 25 anos na certidão de idade, quando se tem menos de 25 anos no corpo e no espírito? Isso, sem repetir que há grande diferença entre ser velho e sentir-se velho; mas, esta já é outra história...

Abramos um parêntesis para algumas considerações sôbre os amores dos velhos.

Recorde-se, de início, noção sobremodo sabida, de que a circunstância de um individuo ser velho não implica, obrigatò- 
riamente, em que deva ser impotente. Assinalando serem extensas as variações á respeito, lembra Almeida Júnior que "ao lado quinquagenário impotentes alinham-se, seguramente, septuagenários de virilidade íntegra". Embora tal não ocorra com frequência manda a verdade reconhecer. Por que, ao dizer de Cícero, não é tanto assim nos anciães, o apêlo da volúpia (non est voluptatum tanta quasi titillatio in senibus). Exemplifica com Sófocles; perguntado, êste, se ainda "conversava" com mulheres(utereturne rebus veneris), respondeu - que não:" de propria vontade, assim como um agreste e máu senhor, fugi e me desacostumei disso"(ego vero instinc sicut a domino agreste ac furioso profugi)

Voltando ao assunto, fôrça é reconhecer haver velhos (cronológica, não psicofisiològicamente falando) que amam, se apaixonam, querem casar-se, quando não procuram "soluções" outras. Dá-nos notícia Ramon y Cajal de casos excepcionais da conservação do impeto genésico em alguns homens famosos, na idade provecta, como sejam Herschel, Virchow, Verdi, Ibsen, etc. Tinha Catão, o censor, 80 anos quando, de visita a uma nora, lhe seduziu a mais moça das escravas; Victor Hugo, octogenário já, amava, com ardor, a encantadora atriz Juliette Drouet; de Goethe, conta-se que, aos 75 anos, se apaixonou perdidamente de Ulrica Levetzow, de 18 anos, com a qual se quís casar, tendo sido porém, diplomática mas firmemente, recusado; Gabriele d'Annunzio, velho já, seria, ao que se conta, amante ardoroso de jovens fascinadas por seu talento; revelou o secretario de Anatole France que êste, ainda depois dos 70, arrebanhava muìheres na rua, para o amor; conta-se que o famoso Thomaz Parr teria sido condenado, aos 118 anos, por ... adultério; diz-se que Bernard Shaw, já velho, se apaixonou da jovem e bela Sza Sza Gabor; tendo-lhe alguém falado a respeito, respondeu: "que quer? só se têm 80 anos uma vez na vida...".

São, porém, exceções. A confirmarem a regra. E esta é, no caso, a decadência da velhice. Que amargura e envenena a vida a pessoas sem conta. Mulheres, em particular, que se toturam nos calvários dos institutos de beleza, na busca do impossivel. 
Só mulheres? Não, também aqui, poderemos, com La Fontaine, recordar qu'il y a bon nombre d'hommes qui son femmes...

O normal nos amores outonais do homem é que êsses amores são fugazes. Fogo de jacá velho: muito vivo, muito alto, muito estralejado, mas de pouca duração; nem cinza deixa...

Poderão, mais tarde, deparar com a tentação, por mais forte que seja, e não haverá mais perigo. Mesmo que o desejem não mais poderão pecar. Daí, o derivativo inócuo, nos desabafos platônicos, em prosa e verso. Assim: "Você chega com 20 anos de atrazo!" - supira, melancòlicamente, um dêsses ridículos apaixonados, junto ao ouvido de uma jovem, trescalante de juventude; ou então, como Guilherme de Almeida:

Fico - deixas-me velho. Moça e bela

Partes...

E há os que, imploram a exemplo de Gilberto Amado:

Não lances achas na fogueira morta

Deixa a cinza dormir, tranquilamente,

Aquecida ao calor da última brasa

Podem, parafraseando Renan, clamar: "Tard je t'ai connue, beauté parfaite!'. Bem tarde, com efeito. Podem mesmo adaptar ao seu caso caso os lindos versos de Castro Alves:

É tarde! É muito tarde! o templo é negro...

$O$ fogo santo já no altar não arde.

Vestal! não venhas tropeçar nas piras...

É tarde! É muito tarde!

É, sem dúvida, o mais triste dos lamentos, da parte de quem se sente incapaz para as coisas da vida que foram belas, mas, no momento, nada mais são que lembranças, recordação, saüdades...

Restar-lhes-á, depois, o consôlo de recordarem o passado. Dirão, com saüdade, o olhar úmido perdido na distância: "No meu tempo..." - e já estarão, de fato, velhos.

Porque o saudosismo é apanágio da senectude. Consola, 
conforta, ajuda a viver. E que mal haverá em rememorar proezas e façanhas amorosas, se isso já passou, se isso morreu se isso não existe mais - se isso já foi ontem?...

Teria razão La Bruyère ao afirmar - "c'est une grande difformité dans la nature qu'un vicillard amoureux?" Segundo Licurzi, dever-se-ia recordar a êsses tenórios idosos os seguintes versos:

Viejo que por amor sufre y se apena

Merece la horca y la cadena

Comuns, nos velhos, êsses amores crepusculares, outonais, tardios "quando o espírito começa a ouvir, ao longe, o toque de recolher", dizia Nabuco. Talvez por isso houvesse Anatole France dito ser a velhice "inverno da vida, sujeita a tempestades".

Há na vida do homem, quando chega o crepúsculo e a noite da velhice se anuncia, uma como que volta à... juventude.

Falamos em tese, está claro. Fugindo ao risco das generalizações. Sabido ser perigosa tôda generalização - mesmo esta, contida na presente frase.

A essa "adolescência da velhice", chamou Maurice de Fleury le rétour d'âge. Ou, como querẹm outros, sol de outono, que o outono precede, de .pouco, o inverno trazendo, seu sol último e efêmero calor, antes do frio definitivo que, implacável, se avizinha.

Nos Estados Unidos, costuma-se observar, pelos fins do outono, um surto brusco de calor. Embora muito quente, é, algumas vêzes, a época mais linda do ano, Dura pouco, entretanto; de repente, numa noite, se passa, sem transição, do calor escaldante ao mais glacial dos invernos. A êsse veranico, os ianques denominam verão indiano; por analogia, designam verão indiano ao fogacho passageiro que se observa na vida do homem.

À urticária amorosa dos velhos e madurões, chama o paranaense brotos joaninos: brotos que irrompem fora de tempo, em árvore velha perto de secar. 
Adolescência da velhice, rétour d'âge, sol de outono, brotos joaninos - tudo vem dar no mesmo: visita-da-saúde daquilo que não tardará a perecer.

Por espaço de tempo transitório, mas nem por isso menos perigoso, valve o indivíduo às loucuras dos 17 anos. Exarcerbase-lhe a sêde de afeto, ternura e carinho. Desvairado, pensando que o mundo vai-se acabar, nada querendo perder, atira-se, com sofreguidão, sem medir consequências, às fontes mesmas da vida, na ânsia de colhêr os derradeiros prazeres que esta lhe possa proporcionar.

A essa altura, a espôsa - companheira de muitas lutas vivendo o penúltimo ato da sua tragédia biológica de mulher, navega, desarvorada e sòzinha, no mar borrascoso do cabo-dastormentas da menopausa.

Enquanto isso - confrangedor paradoxo! - renascem, no marido, todos os ímpetos do verdor dos anos, quando a vida só parece oferecer trincheiras a tomar, barricadas a defender, serenatas d'amor, balcões a escalar. Tumultua-lhe, no peito, um sangue reaquecido por seródios harmônios; parece-lhe, a êle, que o coração lhe pulsa como se adolescente fôsse; povoam-lhe a imaginação velhos romances mal vividos... e que sonha reviver ainda.

Abre-se, temporàriamente, uma janela ao diabo. Daí, os amores fulminantes, a fugas românticas, os escândalos e complicações sentimentais dos madurões, arrastados, muitas vezes, por jovens inda tenras, prêsa fácil, outras vezes, de astutas cavadoras de oiro.

Não bastasse o descontrồle, o desgovêrno da sua conduta, e vão além; como que se metamorfoseam: transmutam-se maridos amantíssimos em tiranos domésticos; passam a andejos boêmios os que, dantes, pagavam para não sair de casa; fazemse avarentos os pródigos; fazem-se perdulários os avarentos; fases de injustificada euforia alternam-se com crises da mais sombiria depressão; fleugmáticos transformam-se em estourados, irritadiços.

Razão de, essa, ser uma idade perigosa - crítica mesmo - 
a idade da impulsividade pronta e irrefletida, das grandes oscilações afetivas, da emotividade fácil no mais estranho dos sentidos. Em que a pessoa pode ser levada a matar-se. Dir-se-á, mais tarde, que foi o tédio; spleen, dos inglêses; kief, dos árabes; candra, dos russos; cafard, da Legião Estrangeira; acédia, dos conventos da Idade Média; banzo, dos escravos africanos variam as denominações, mas a nostalgia é a mesma. Uma crise depressiva, a nuvem negra da melancolia, a angústia estraçalhante, um raptus ansioso - e sairá, violentamente, da vida, através da porta do desespêro. $\mathrm{E}$, às vezes, de maneiras que impressionam, como relatamos em nosso livro sôbre o suicídio (*).

Fase em que à mulher atitude não sobra (mesmo porque outra não adeantaria...) senão perdoar; com a mesma tolerância com que se relevam tropelias e imprudências de um filho que ainda não acertou passo na vida. Certa de que mais cêdo ou mais tarde, o marido, cansado de "violências" para as quais a natureza acabará negando o fôlego necessário, retornará ao redil conjugal, desiludido, cheio de arrependimento, manso e humilde, saudoso da poltrona preferida, do velho cachimbo, do chinelo cômodo, e - por que não dizer? - saudoso da velha companheira.

Descrevendo essa "vadiação no caminho da morte", assim se expressa o escritor René-Albert Guzmán, autor da novela "Ciúme":

“Andava êle pela idade de bifurcação. Deixamse, uns, levar pela estrada, cada vez mais mole e escorregadia. Outros, sentindo, pela primeira vez, o vento frio que vem de baixo, enrijam os músculos, retardam o passado, metem-se por todos os atalhos, afim de lhes gozar as vóltas e surprezas. Desejam sentir, sob os pés, não o choque duro das cidades, mas a resposta amiga da terra, caminhar pelos bosques,

(*) “O SUICÍDIO, EM FACE DA PSICOPATOLOGIA, DA FILOSOFIA, DA LITERATURA E DO DIREITOk - Livraria da Revista Forense - Rio. 
lançar mão de tôda prêsa apetecivels uma lebre, uma flôr, um tesouro escondido, o anel dos Niebelugen, uma camponesa; respirar uma brisa que, de súbito, se levanta, trazendo o perfume de um vale próximo - o mais belo de todos! - ainda não alcançado, mas onde se espera chegar; saborear as únicas iguarias que convêm a êsses conhos: pássaros delicados, cujos ossinhos se desfaçam entre os dentes; frutos que ainda retenham um raio de sol; vinhos de inolvidável degustação..."

Impossível retratar melhor a inquietação psicológica de seu personagem, homem maduro, apaixonado por encantadora jovem e que, acicateado pelo mais móribdo dos ciúmes, culminaria no crime.

"De criatura assim se poderia, com o francês dizer que, vive "remuant encore des cendres éteintes que les derniers soleils de la vie ne rechaufferont pas".

Que a velhice não põe paradeiro à espermatogênese é noção de sobra conhecida. É esta, possível em ancião de 80 anos, 90 anos (segundo Pavlov) e mesmo 100 anos (de acôrdo com Metchnikoff). Respeito à secreção interna do testículo tenderá, é claro a, progressivamente, diminuir. Em alguns casos, poderá, entretanto, evidenciar transitória, mas apreciável, exarcebação. Voltaremos ao assunto.

O que nos velhos, comumente, se observa é a impotentia coeundi - "incapacidade instrumental" ao dizer dos autores italianos, por esclerose dos vasos penianos, impedindo a ereção - conservada, porém, habitualmente, a potentia generandi. Ao vêr de Zacchias, o homem teria aptidão procreadora até os 72 anos, embora Strassmann, judiciosamente, opine "que não se deve maliciar da autoria dos filhos dos velhos, mesmo além daquela idade".

Casos há em que, no velho, é o início da senilidade assinalado por uma excitação sexual, um como que despertar do ímpeto genésico adormecido; continuam outros, porém, mais ou menos impotentes, embora se possa, nêles, acirrar a libido. 
Estudando a etapa final da vida sexual, o climatério - para alguns monofásica, para outros, difásica - assinalam os que pensam da última maneira, haver, em ambos os sexos, verda. deiro difasismo: uma fase, inicial, de exacerbação da sexualidade, na qual a líbido como que passageiramente se revigora, seguida de uma fase de verdadeira involução, Traduzir-se-ia o eretismo genital, no ancião - geralmente "funcionando no vasio", na pitoresca espressão de Levy-Valensi - pelo uso de palavras obcenas, pela predileção por palestras imorais, por anedotas picantes, pelas perversões sexuais, por atentados ao pudor, etc.

Assinala Guelman, já citado, que o debilitamento da potentia coeundi e simultânea conservação da libido, constituiriam uma das "desarmonias do envelhecer humano". Na sennilidade, diz, desapareceria o impulso de amplectação (tendencia à posse carnal), restando apenas o de contrectação (tendencia à aproximação física com o sexo oposto.).

Focalisando o que ocorre no velho - impotentia coeundi, por impossibilidade de ereção e persistência da secreção interna, testicular - pergunta Afrânio Peixoto: "entre esta impotência de meio e essa possibilidade de recursos, não estará explicada toda a excitação, coacta, por isso pervertida da senilidade?"

"In parte, si tratta de condizione strettamente somatiche (aumento numerico delle cellule intertiziali del testicolo, adenomi multipli corticali delle surrenali, congestione dei centri lombari per $i$ lunghi decu biti e par la scarcezza della vita attiva; ipertofia prostatica com più frequente accumulo di urina in vesica e, consequentemente, difficultado deflusso del sangue refluo dal'asta con stasi nei corpo cavernosi. In parte sono in giuoco condizioni occasionali; come la difficoltá di unirsi con persona relativamente giovani dell'altro sesso; da ciò esacerbazione della libidine no soddisfata e non placata, quiddi, dato lo squilibrio frequente, tra il potere ed il volere, tra ciò che la terda vollutà suggerische e ciò que per- 
mette - o meglio non permette - la deficiente erigibilità dela verga, ne deriva il retorno del vechio el forme infantili di senssualita (voyeurs, frotteurs, esibizionisti, masturbatori senili)" (Altavila).

Ao ver de Benjamim Spota, dever-se-ia a exaltação da libído à hiperfunção, episódica, gonadotrófica e a processos de hiperplasia prostática. É Guelmann de parecer que tal exaltação se deva ao aumento do tono hipofisário. Diz o mesmo autor que o aumento da atividade da hipófise parece ter por fim estimular o mais possivel a função de orgãos decadentes, mas que logo sobrevém o esgotamento dos próprios tecidos. "Podemos comparar êste fenômeno vital ao que ocorre entre um cocheiro e seus cavalos, em uma grande e forçada viagem. Quando os cavalos começam a cansar-se, castiga-os o cocheiro, cada vez mais vigorosamente, mas como aqueles não mais podem reagir, acaba o cocheiro por também se esgotar".

Possibilidade a encarar, no casamento dos velhos, é o casamento "ancilar" (do latim ancila, ae: criada), Embora alguém houvesse definido a velhice como aquela "idade em que o homem presta mais atenção à comida do que à criada", o certo é que,, muitas vezes, ocorre exatamente o contrário. Por fôrça de hábito, ou porque serviçal arguta manobre, habilidosamente, no sentido de melhorar sua situação, pode o ancião ser levado ao casamento com a criada que se soube fazer indispensável. Já tem acontecido, acontece ainda, acontecerá sempre. Um exemplo apenas: o de Benevenuto Cellini que, aos 64 anos, se casou com a governanta.

Outras vezes, mostra o velho pendores pelo matrimônio, geralmente com criatura mais jovem (himenomania), pelo que se denomina tendencia gerocômica, buscando aquecer o gêlo de sua anciania ao calor do corpo de uma criatura estuante de seiva, pujante de juventude.

A exemplo do que fez o velho rei David, conta a Bíblia, no Primeiro Livro dos Reis, 1 a 4 : 
“1. Sendo, pois, o rei Daví já velho, e entrado em dias, cobriam-no de vestes, porém não se aquecia

"2. Então disseram-lhe os seus servos: Busquem para o rei meu senhor uma moça virgem que esteja perante o rei e tenha cuidado dêle: $e$ durma no seu seio, para que o rei meu senhor se aqueça

“3. E buscaram por todos os termos de Israel uma moça formosa: e acharam a Abisag, a Sunamita; e a trouxeram ao rei

“4. E era a moça sobremaneira formosa: e tinha cuidados do rei, e o servia; porém o rei não a conheceu"

É mais frequente o casamento de velho com moça, que de moço com velha, Relativamente frequentes, nos últimos tempos, o casamento de moças com velhos.

- Que levará criatura jovem a consorciar-se com pessoa idosa, agarrando-se, como hera tenra, a um velho muro, prestes a cair? Amor? - é duvidoso; compaixão? - pode ser (*); admiração pelo talento da criatura idosa, admiração que se transforma em amor e desejo de ficar sempre ao lado, servindo-a, como espôsa? - algumas vezes (caso de Oona O'Neil e Charles Chaplin); insuficiente liquidação de Complexo de Édipo (caso de moço que se casa com velha) ou de Complexo de Eletra (caso de moça que consorcia com velho)? - é uma hipótese; necessidade de quem a ampare, sustente (e aos seus, geralmente), e não importune muito? - bem possível; má fé, objetivo de auferir vantágens, presentes ou futuras? muitas vêzes;

Abstração feita de casos, que os há, em que isso poderá ser modalidade de... gerontofilia.

(*) Bela mulher francêsa, à qual o magistrado falava da paixão que ela tivera por um velho, respondeu, profundamente: De la passion, oh! non, Monsieur le Juge, dites de la compassion!" 
Que levará, pergunte-se agora, pessoa velha a querer casar-se com jovem? Paixão? - é possivel (caso de Goethe com Ulrica de Levetzow); necessidade de afeto, ternura, carinho? pode acontecer; compaixão? - é duvidoso; precisão de quem lhe olhe a casa, cuida a roupa, prepare os alimentos e sirva de enfermeira? - quase sempre.

Casos há em que casamentos assim podem ter o "valor sintomático" de uma demência senil, seja no seu período médicolegal (*), seja no período de estado.

Casos há, ao reverso, em que a circunstância de o sênio querer convolar núpcias com pessoa jovem, de modo algum tem o mesmo significado. Não são raras as arremetidas de parentes mal intencionados que, por isso, procuram se valer da Justiça para impedir ou anular matrimônios dêsse tipo. Fala, aqui, Legrand du Saulle na convoitise mal deguisée de son entourage, l'avidité de quelques parents. Mais de uma vez - observa Castelnnau - las spoliation des interêts a éte le véritable but des demandes de interdiction. Cumpre então à Lei - que Anatole France definiu como "a administradora dos instintos" - impedir tais arremetidas.

Passemos a exemplificar com caso nacional, ocorrido, há anos, numa das nossas grandes capitais, com a sogra, sexagenária, de conhecido político de outrora (daí, o silêncio da imprensa, na época), viúva ainda bonita, que se apaixonou por um rapaz que bem poderia ser seu neto. O genro, assustado, tomou imediatamente, medidas visando proteger o patrimônio (uma das casas exportadoras mais importantes do país) que julgava comprometido. Nada conseguindo, foi além: tratou

(*) Fala-se em "período médico-legal" de uma psicose sempre que, muitas vezes antes que esta se patenteie a olhos leigos (e mesmo de médico não psiquiatra), se tornam evidentes perturbações do caráter e do senso moral, mudança nos hábitos e costumes, com a prática de atos em flagrante contraste com a maneira anterior de agir e de conduzir-se do indivíduo.

Para maiores detalhes sôbre êste ponto, leia-se nosso livro "PSICOLOGIA FORENSE E PSIQUIATRIA MÉDICO-LEGAL", capítulo Limites e modificadores da capacidade civil e da responsabilidade penal", ítem "Período médico-legal das psicoses". 
de promover seu internamento, em frenocômio, como... louca. Saía a velha dama de um salão de beleza, devidamente "recondicionada", quando foi prêsa, sob protestos, e levada para uma casa-de-saúde, onde esteve "incomunicável" durante... cinco anos. Evoluíndo a situação política, com a perda de prestígio do genro, poude a "louca" recuperar a liberdade e - o que é de se admirar — ainda sã da mente!

Em França, aconteceu fato igual, sendo que, lá, a pobre sogra permaneceu internada sete anos; provada sua sanidade mental, processou o genro que, após longo debate judicial, foi condenado a lhe pagar vultosa indenização.

Caso parecido - êste, com sogro velho capitalista, vitima da "impaciência" de filhos e genros - ocorreu, também, entre nós, na capital do Paraná, e não faz muito, mas esta é outra história, bem interessante por sinal, que relataremos um dia, logo que a Justiça se haja pronunciado a respeito.

Lição que Magistrados e juristas devem guardar: escândalos, assim, de modernas Bastilhas, são mais comuns do que se imagina; e mais, de par com o perigo que, em casos assim, representa a cubiça e a desonestidade de parentes pouco escrupulosos, há que ter em mente outro perigo mais grave que todos: o de certos "peritos", casos - êstes, sim - dignos de estudo...

E que levará - indague-se, por fim - uma pessoa velha a querer casar-se com pessoa igualmente velha? Informa Gorriti que, em alguns dos gerocômios de sua pátria, o "ardor" amoroso de alguns anciães acarreta não poucos trabalhos à administração, que os tem de trazer sob vigilância, "pues no es raro el caso de encontrar entre ellos Tenorios y Ineses". Conta o caso de uma anciã, cortejada por um ancião, alí recolhido, que não ocultava seu desejo de vir a casar-se com seu eleito, evidenciando uma candura de ilusões admirável, arquitetando planos relativos à nova existência, ao futuro...

Ridiculariza-se, amiúde, o velho apaixonado, na literatura, no teatro, no cinema, etc. Lembre-se, porém, em defêsa des- 
se amaroso seródio que, tirantes casos, relativamente raros, em que é levado ao crime, não são comuns tragédias passionais pelos mesmo provocados.

Desnecessário fixar que uma criatura bem avançada em anos, mas em condições psíquicas satisfatórias, pode querer casar-se por motivos prefeitamente explicáveis (necessidade de alguem que lhe assista os negócios, por exemplo). Tal é o caso, corrido nesta Capital, e que a seguir resumiremos:

M. C. P. brasileira, branca, viúva, 76 anos, dona de imóveis e outros bens de fortuna, entendeu de casar-se com N. R. J., português, industrial, de 67 anos, velho amigo que, havia muito, lhe vinha gerindo, satisfatòriamente, os negócios. Não tinha M. C. P. ascendentes nem descendentes; tinha, porém, um irmão, cujo filho, moço pobre, fizera ela educar, à própria custa, até vê-lo formado em Medicina. Em face do casamento projetado, alarmou-se o irmão, por motivos fáceis de compreender, requerendo-lhe a interdição. Dizia êle achar-se a irmã "tomada da mania de casamento, invocando figuras imaginárias como seu noivo, fato êste que, por certo, despertou interêsses de terceiros que, ao que consta, estão subterraneamente consertando um casamento com ela".

Agora, um retrato de M. C. P.: alta, bem nutrida, cuidada nas vestes, bem posta, gesticulação e mímica adequadas, locomovendo-se normalmente, agradavel de tráto, respondendo com acêrto ao que se lhe pergunta, revelando mesmo apreciável agilidade de espírito. Procura explicar seu desejo de casar-se não como fruto de um imperativo sentimental, mas como uma necessidade criada pela sua condição de viúva, a carecer de alguém que, mais de perto, lhe assista aos negocios - no caso, quem já fôra amigo do seu marido e que, havia muito, lhe vinha prestando boa e honesta assistência.

Perícias, feitas, durante dois mêses consecutivos, por médicos locais, evidenciou que

"a despeito da idade avançada da examinanda e das leves restrições oferecidas ao desdobramento de sua função mnêmica, podem afirmar que nela só encontraram o natural desgaste próprio da idade, afiançando, por conseqüência, que a examinada se encontra em perfeito estado de sanidade mental". 
A vista do que o sr. Curador Geral foi de opinião se indeferisse o pedido "em face da prova contrária que se fêz da existência de qualquer anormalidade mental na pessoa de M. C. P." A esta altura, suicidara-se o noivo, envergonhado pelo triste papel que se lhe quisera emprestar no caso. Dois anos depois voltou à carga o irmão de M. C. P.; requerendo-lhe, de novo, a interdição, acabando, porém, por desistir da ação.

Depois de lembrar que todo um ensaio poderia ser escrito sobre o casamento dos velhos, dá-nos Alves Garcia, judicioso parecer, respeito à anulação do casamento de anciã com criatura jovem.

Dâmos-lhe a palavra: "A lei tende a ser liberal em tais casos e, em minha opinião, isto é assunto para experiência sempre renovada, sendo dificil anular o casamento consumado". Depois de analisar os possíveis interêsses que levam o velho a casar-se com moça, ou vice-versa, conclui: "Ora, a lei não sóde anular o casamento só porque, atraz dêle, existam tais interêsses; se o consentimento foi legal, as razões dêle não importam muito. É surpreendente verificar como os anciãos são levados, facilmente, a êste tipo de matrimônio; mas, é penoso anulá-lo, pois em tal caso a separação significa a morte rápida do velho, ainda que a anulação seja pleiteada com sólidos fundamentos, em atenção à respeitáveis interêsses de família".

Recorde-se, a esta altura, que o velho pode ser vítima de falsa acusação de atentado ao pudor contra menor,obrigado a casar-se com a mesma, não obstante clamar por sua inocência, sem que seja ouvido. Relataremos, a seguir, caso de nossa observação, ocorrido no Paraná, que ilustrará o que acabamos de dizer:

J. B. V., brasileiro, branco, viúvo, 63 anos de idade, professor normalista, gosava de ótimo conceito na cidade paranaense de C. L., sendo, alí, diretor de um grupo escolar. Frequentava êste, na qualidade de aluna, a menor M. L. B., de côr branca, de 14 anos de idade. Esta, já então sujeita "a acessos nervosos" (de que inda hoje sofre, e por nós testemunhados, de natureza nitidamente pitiática), durante os quais "sentia uma coisa entrar dentro de seu corpo", pondo-se a gritar, rasgando as vestes, desnudando-se, etc. Como a menor tivesse sido vista ir, vezes seguidas, ao gabinete do velho professor, passaram a correr rumores de que o velho estaria com ela mantendo relações sexuais. Interrogada, severamente, pelo cu- 
nhado "que queria saber tôda a verdade", negou tudo; depois, à medida que mais a solicitava a que "contasse, direitinho, se o professor havia feito isto, aquilo e aquilo outro..." admitiu, relutante, que talvez fôsse verdade; por fim, anuindo, concordou com tudo. Grande o escândalo na cidade, tendo sido o professor demitido do seu cargo, e tudo o mais. Mandada M. L. B. a exame por médico, hoje falecido, opinou êste "que estava deflorada". À vista do que - malgrado a energia com que o velho professor negava quanto se lhe acusava - o obrigaram a casar-se com a menor, o que foi feito tendo, a seguir, ido cada um para seu lado. A história não parou aí. Uma semana após o casamento, como a recém-casada se queixasse de distúrbios menstruais, trouxe-a a mãe a Curitiba, ao Dr. V. F. A., competente ginecologista e obstetra, que a examinou detidamente constatando ser a mesma ainda... virgem, e mais, portadora de himen que, por sua disposição anatômica, não permitiria a cópula sem deixar vestígios. Mesmo assim, nada se fêz para reparar o êrro.

0 velho professor, corrido de vergonha, não levou muito a morrer. A "viúva" liquidou o que deixou, esbanjou tudo em seguida entregando-se à prostituição, o que ainda faz, continuando a ter vez por outra, seus "acessos de nervos", durante os quais sente "uma coisa" entrar no seu corpo, e põe-se a gritar, rasgando as vestes, desnudando-se...

Não temêssemos nos alongar em demasia, e recordaríamos, a propósito do caso acima, algo do que Dupré escreveu sôbre a mitomania. Pode ser, esta, observada na histería; em personalidades psicopáticas (especialmente nos psicopatas ostentativos: mentirosos mórbidos, de acôrdo com Schneider; defraudadores, segundo Kraepelin); nas oligofrenias, na debilidade mental em particular; no início da esquizofrenia, etc.

A menor de outrora, causa do traumatismo moral que vitimou um velho mestre inocente, e a prostituta de hoje, que bate as calçadas da capital paranaense - era, é ainda, uma autêntica histérica, sofrendo da mitomania (tendência patológica à fabulação e à mentira). Palavras de Alcântara Machado: “A histérica é a grande simuladora, a mentirosa por excelência, tôda ela é mentira", e acrescenta: "Mentira coerente, mentira estável, mentira terrível: a doente compõe, com grande luxo de pormenores, as histórias mais complexas, referindo-as no tom de convicção mais profunda, documentando-as com provas que teve o cuidado de fabricar, com surpreendente malícia. Impressiona, persuade, convence".

Dentro do mesmo panorama de velhos injustiçados, que 
pagam por um crime sexual que não cometeram, relembremos a chantage du viol, bem estudada por Fournier:

Chantage du viol - Meninas "preparadas", apresentando traumatismos adrede produzidos, ou então portadoras de vulvites devidas a outras causas, são levadas por criaturas sem escrúpulos à autoridade, ante a qual - repetindo lição cuidadosamente ensinada e ensaiada - acusam, falsamente, determinado indivíduo como autor dos primeiros, ou responsável pelas segundas, em consequência a atentado contra o pudor". Só chegam perante a autoridade - é claro - depois de haverem falhado ameaças contra o "acusado" (quase sempre velho, e de posses). Trata-se de modalidade de mentira infantil não patológica, sugerida ou ensinada.

\section{PERÍCIA}

Nunca é demais encarecer a importância do médico, funcionando na qualidade de perito, como colaborador do Magistrado, do advogado, do penitenciarista, nos diferentes departamentos do Direito, dando a "interpretação médica das diversas condições patológicas, em suas relações com a ação judiciária" (Claude). No fôro cível e no fôro criminal, isso sem levar em linha de contas outros aspectos que não detalharemos, para não mais nos alongarmos. Daí, a razão do asserto de Mestre ilustre, ao dizer que "a perícia é, muitas vezes, o prefácio da sentença".

Indefensável, de todos os pontos de vista, a desestima que juristas mal informados (raros, felizmente) votam ao médico, quando a serviço da Justiça. Indefensável também - mas perfeitamente compreensível - a fúria com que juristas (mercê de Deus, raríssimos) se atiram contra os psiquiatras, quando chamados a opinar, como peritos, escalpelando-os, impiedosamente, procurando até negar-lhes o status científico que a experiência e os estudos lhe deram; fúria indefensável, mas compreensível, dissemos, por isso que êsses juristas "psiquiatrófobos" são sem dúvida, todos êles, casos para... psicanálise: combatem justamente o que temem.. Não, cabe falar, aqui, com Foerster, no "perigo funcional" (Berufsgefahr) dos alienistas, na opinião de Nelson Hungria "sempre inclinados a divisar o patológico em qualquer reação mais aguda do psiquismo, quando não a exagerar a influência de morbus, acaso existente". Não 
será tal maneira de pensar, ela sim, um "vício de refração", u'a maneira distorsida de encarar o problema? É hipótese a meditar...

Ninguém ignora que a opinião do perito não vincula a opinião do juiz; longe vai o tempo em que Ambroise Paré pontificava: "Os juízes julgam conforme o que se lhes relata". Embora concordando com Coll, quando êste afirma não ser, o juíz, "um conviva de pedra", repitamos, com Aschaffenburg, que o juiz deve conceder ao perito - cuja escôlha está nas suas mãos -- a mesma confiança que deposita no engenheiro que contratou para construir uma casa, cujo juízo sôbre a estática do arcabouço êle tampouco poderá conferir.

Quando lemos, em penalista de grande prestígio de nossos dias, que o juiz não está inexoràvelmente adstrito à consclusão pericial, especialmente no que diz respeito à inexistência das condições psicológicas da responsabilidade - recordamos sábia lição de Nima Rodrigues, nêste particular, quando ensina que a função de julgar se reduz, em derradeira análise, a um problema de psicologia prática: apurar e medir a responsabilidade do transgressor da Lei. Damos-lhe a palavra: "Mas, sendo a insanidade mental a mais poderosa dirimente da responsabilidade e da capacidade e, ao mesmo tempo, na sua qualidade de estado mórbido, de alçada imediata da apreciação médica, compreende-se que é a perícia psiquiátrica aquela a que cabe precedência sôbre tôdas as demais perícias - médicas ou outras por que é aque está proxima da função do juíz, a quem tocà reconhecer a existência de um crime ou a validade de um áto civil, afirmando a responsabilidade inteira ou a plena capacidade do agente". É aqui que, com razão, se podem invocar palavras de Alcântara Machado: "os peritos são os olhos do juíz".

Na apreciação da capacidade, ou seja, aptidão para a vida civil, é o perito a muitas vezes, chamado a opinar se determinado ancião é, não, capaz para gerir sua pessoa e administrar seus bens.

Verificada a incapacidade absoluta e permanente, ou relativa e temporária, para os atos da vida civil, ser-lhe-á, nos termos do artigo 615 do Código de Processo Civil, decretada, pelo 
Juíz, a interdição e deferida curatela plena ou limitada, fixada, no segundo caso, as restrições de capacidade a que ficará sujeito o interditado. Para a execução de sua tarefa, levará o perito a efeito um exame meticuloso do interditando; não só de sua vida pregressa, peculiaridades temperamentais e caracterológicas e suas atividades, como, também, exame direto do indivíduo, levado a efeito com método e rigorismos ciêntificos, repetido, muitas vezes,em hora e dias diferentes, de preferência sob a forma de interrogatório-conversação, afim de poder chegar a uma exata conclusão. Se casos há em que distúrbios psíquicos se evidenciam desde logo, a incapacidade de o observado auto-conduzir-se na vida - passível, pois, de interdição plena - casos outros há, ao reverso (no período médico-legal de psicose, por exemplo), em que a tarefa do perito se torna menos fácil. Casos há, finalmente nos quais nomes ilustres (Tardieu, Krafft-Ebing Legrand du Saulle, Nina Rodrigues, Ruiz-Maya e outros) acham "aceitável e aconselhável" incluir a "decrepitude fisiológica como um dos motivos de incapacitação", embora ressalvando "mas, sòmente quando as circunstâncias sociais o ditem, sem que isso adquira, em nenhum momento, caracteres de regra geral" (Alves Garcia). Discordamos; achamos arriscada a adoção de tão perigoso critério, dada a possibilidade de abusos: sendo, a incapacidade, a "morte civil" (Weygandt), só em casos especiais, e bem caracterizados, deverá ser decretada.

Distúrbios mentais psicógenos, episódicos, delirantes, catatímicos, etc. - ruidosos, porém transitórios, de curta duração, tendo aparecido em indivíduo, até então normal do psiquismo, pôr fôrça de vivências anormalmente desfavoráveis e tendo passado sem deixar vestigios - não servirão, a, por si sós, justificarem a interdição, e nem deverá o perito aconselhá-la. Tivemos oportunidade de, em outro trabalho, estudar sugestivo exemplo a respeito. Lembramos, de passágem, a titulo ilustrativo apenas, sábio conselho de Ramon y Cajal, a respeito de ancião graforrêico, que se entregava a enviar cartas mais ou menos comprometedoras, ou "a pedidos" inconvenientes para os jornais. Em casos assim, ensina o ilustre mestre espanhol a, "antes de qualquer outra providência remeter êsses escritos, para exame, a um psiquiatra amigo"... 
A possível ocorrência de psicoses " $n a$ " velhice (e não " $d a$ " velhice), passiveis de cura, em anciãos cuja interdição é requerida sob tal fundamento, suscitarão questões a serem resolvidas pelos peritos, levados em linha de conta, em cada caso, os gráus de cura ou remissão, duração das mesmas, etc.

Se anteriormente interditado o indivíduo, por fôrça de uma dessas psicoses, poderá sua interdição ser levantada nos casos de remissão completa ou bôa, e com duração julgada adequada; leiam-se, a respeito, magníficos trabalhos de Nerio Rojas e Hélio Gomes.

A circunstancia de, não obstante amnésia anterógrada $(*)$, conservar o velho a recordação, viva e nítida, de fatos passados, remotos por vêzes, poderá induzir a êrro leigos (e mesmo médicos desconhecedores dêsse detalhe), que poderão fazer um falso conceito de que há sanidade psíquica, só porque há "boa memória". Ouvem-se, habitualmente, da parte de advogados e até de Magistrados - afirmativas como esta: "Como se poderá dizer que êste indivíduo está enfêrmo da mente, se tem u'a memória admirável, sendo capaz de contar, com exagêro de minúcias, o que lhe aconteceu em diversas fases da vida?" De acôrdo; é sempre boa - ótima mesmo - essa memória dos fatos passados no sênio, razão de ser tôdo velho, um laudator temporis acti. Nos começos da involução senil - e antes que a demência se instale de todo - essa "boa memória" se conserva; mas, apenas para fatos idos. Façam uma investigação da memória de fixação: mandem o examinando relatar fatos recentes, ocorridos na véspera até; façam-no repetir palavras ditadas; mandem-no reconhecer objeto anteriormente mostrado e identificado por êle - e verão que sua capacidade mnéstica está gravemente comprometida.

Exemplo do que acabamos de afirmar foi o famoso caso Sagrerra, ocorrido na Espanha, em 1862:

(*) A amnésia (perda da memória) pode ser: anterógrada, ou de fixação incapacidade para fixar fatos e coisas recentes; retrógrada, ou de conservação, - perda das recordações já gravadas na memória; retro-anterógrada, total, encontradiça, esta, no último estádio das demências orgânicas. Isso, sem contar a amnésia lacunar, observável, por exemplo, na epilepsia, correspondente às crises. 
Uma certa senhora Sagrerra, recolhida a um hospital para doentes mentais, fêz grande alarde para sair do mesmo e, tão logo o conseguiu acionou seis pessoas, inclusive dois médicos. Era notória a insanidade mental dessa criatura ("histérica, sujeita a acessos de melancolia, alucinada e, de um certo tempo a esta parte, manifestando perversão moral extrema" - escreveu-se); atestaram-no testemunhas de tôdas as classes sociais o que de pouco valeu, tendo sido os acusados condenados, alguns a 18, outros a 20 anos de prisão. Quís o Tribunal ouvir a opinião de médicos a respeito. Dirigiu-se, para tanto, à Academia de Valença. Pois bem, "les chirurgiens, médecins d'enfants, oculistes, accoucheurs, qui composaint la trop savante Academie de Valence, répondirent que la dame Sagrerra, ayant conservé la memoire, ne saurait être folle". $\mathrm{E}$ mais (maneira de pensar de muito médico de hoje, assinalese) que "celui qui se rapelle dans les plus petits détails, ce que lui arrive pendant le temps qu'il a passé pour fou, donne une preuve evidente de l'integralité parfaite de ces facultés intellectueles".

Graças ao parecer desses membros da Academia de Valença - bem intencionados sem duvida, quiçá competentes nas suas respectivas especialidades, mas pouco afeitos ao tráto com enfermos da mente - se deveram as condenações a que fizemos referência. Acrescente-se para finalizar, que as vítimas desse êrro judiciário continuaram lutando, tendo, mais tarde, sua pena de prisão transformada em exílio, sendo, posteriormente indultadas.

Eis porque - será preciso repeti-lo? - a perícia de casos assim só deverá ser confiada a psiquiatras experientes e experimentados, por isso que êles, e só êles, poderão, com ciencia e consciência, opinar, acertadamente, a respeito.

Chamado o perito a opinar sôbre a sanidade mental do sênio que deseje convolar núpcias, ou que já o haja feito, principalmente com pessoa mais jovem - recorde o que por nós, foi dito, em linhas anteriores deste trabalho: que uma pessoa de idade avançada, normal do psiquismo, eufrênica, pode querer casar-se, por motivos perfeitamente explicáveis. Citámos caso da que o quis fazer com seu procurador, o que levou interessados a promoverem sua interdição; à pericia psiquiátrica, evidenciou-se ela porém, compos mentis, o que levou o juiz a negar a interdição.

Outras questões periciais podem ser aventadas, cabendo ao perito opinar a respeito. $\mathbf{E}$ de tôda prudência acautelar-se o 
perito contra possíveis casos, de indivíduos idosos mentis non compos, portadores de enfermidades mentais graves e duradoiras que, pelo reticente no relativo ao seu delirio por sua "reserva" e pela compostura, podem aparentar "normalidade" psíquica capaz, de iludir a observador inexperto ou apressado. Relata Ruiz-Maya sugestivo exemplo de um delirante que, na audiência do Juiz, tão lúcida e sensatamente se conduziu, que a todos deu impressão de absolutamente normal, deixando mal colocada a perícia psiquiátrica que o dera como louco. Foi então que, anuíndo ao pedido daquele psiquiatra espanhol, permitiu o Magistrado que o mesmo fizesse algumas perguntas, bem conduzidas, ao indivíduo em referência. Tanto bastou para que se exteriorizasse, em tôda a plenitude, a mais rica e densa trama delirante, incompatível com a pretensa normalidade que, havia pouco, aparentava.

No que diz respeito à demência senil, assinalam psiquiatras ser possível, em alguns, casos, mesmo quando profunda, compatibilidade da mesma com a conservação dos automatismos verbais no convívio social habitual, dando falsa impressão de achar-se a pessoa compos sui e compos mentis. Daí, a possibilidade de, em casos assim, causar surpresa o diagnóstico do psiquiatra "que percebe a vacuidade existente atraz das fachadas em ruinas". Repetimos a Claude, cuja lição, sobremodo interessante nêste particular, merece repetida. Depois de assinalar que todas as formas de demência senil "peuvent coexister avec une conservation de la tenue generále, um comportement en apparence correct, une attitude paraissant normal, au point de vue des relations mondáines et sociales", assinala, logo a seguir, o grande psiquiatra francês que isso, habitualmente, contrasta "avec une langage qui fait éclater la perte de contact avec la réalité". 
Arrematemos, recordando que, em determinados casos, como o que referimos, de um velho professor, falsamente acusado de atentado ao pudor contra u'a menor e que se viu compelido, manu militari, a casar-se com ela - casos há, como êste ou assemelhados, em que se faz necessário perícia mental na "vítima", que poderá, perfeitamente, ser uma histérica fabuladora, mitômana, ou - quantas vezes isso acontece! - "vítima" preparada, com carinho, por pessoa afeita a auferir proventos à custa da chantage du viol. 